九州大学学術情報リポジトリ

Kyushu University Institutional Repository

\title{
A deoxyribonuclease I from rice bran
}

Mukai, Jun-Ichiro

Laboratory of Sericulture Chemistry, Faculty Of Agriculture, Kyushu University

https://doi.org/10.5109/22727

出版情報: 九州大学大学院農学研究院紀要. 13 (3)，pp. 361-368，1965-05. Kyushu University バージョン：

権利関係 : 
Journal of the Faculty of Agriculture, Kyushu University, Vol. 13, No. 3

May 30, 1965

A deoxyribonuclease I from rice bran

Jun-ichiro MUKaI*

Our knowledges about deoxyribonucleases of plant origin are rather scanty as compared with those of animal and microbial origins?") The present work aims at the purification and characterization of a deoxyribonuclease from rice bran. Special efforts were made in this experiment to eliminate the contamination of phosphatases, which are known ${ }^{3,4)}$ to exist abundantly in rice bran, since these were feared to interfere invariably with the identification of the deoxyribonuclease digests of DNA by further splitting off the terminal phosphate bonds.

\section{Materials and methods}

The substrate used for deoxyribonuclease determination is a preparation from calf thymus by the method of Kay et al.") Sodium ribonucleate of yeast purchased from N.B.C. was purified $^{6)}$ and used as a substrate for ribonuclease. Calcium bis-paranitrophenylphosphate was synthesized from commercially available triphenylphosphate (Katayama) by the method of Laskowski et al. ${ }^{7)}$ and was used as a substrate for phosphodiesterase. Sodium paranitrophenylphosphate, used in phosphomonoesterase assay, is a commercial product (Katayama) of a guaranteed reagent grade.

Determination of deoxyribonuclease activity-This was finally established after examination and comparison of several prevailing procedures ${ }^{8-12)}$ adopting a principle of so-called "acid-soluble UV absorption measurement". The procedure in its entirety is as follows. Half a milliliter of the substrate solution (2 mg DNA/ml $0.01 \mathrm{M} \mathrm{NaCl}$ ) was incubated with an appropriate amount of enzyme in $1 \mathrm{ml}$ of $0.1 \mathrm{M}$ ammonium acetate buffer of $\mathrm{pH} 5.5$ for 60 minutes at $37^{\circ} \mathrm{C}$. The reaction was terminated by cooling the mixture in an ice-water bath and precipitating the undigested DNA by adding $1 \mathrm{ml}$ of cold $\mathrm{N}$

* Agricultural Chemistry Institute, Kyushu University, Fukuoka, Japan. 
perchloric acid. After 10 minutes' settling the suspension was centrifuged for 5 minutes at 3000 r.p.m. The supernatant was diluted 10 fold with water and read at $260 \mathrm{~m} \mu$. Appropriate blanks, usually enzyme-- and substrate-, were run at the same time and subtracted from the complete system. One unit of deoxyribonuclease activity is defined to be an amount of enzyme that produces 1.0 acid-soluble optical density/l $\mathrm{cm}$ light path at $260 \mathrm{~m} \mu$ in $1 \mathrm{ml}$ of the reaction mixture under the standard condition stated above. In other words, the enzyme unit can be routinely calculated from the optical density value by simply multiplying by 20 times. Here 2 times multiplication is for dilution caused by addition of the same volume of perchloric acid, and 10 times for dilution for reading. This unit also shows how much of the substrate DNA added was rendered acid-soluble, if one approximates $1 \mathrm{mg}$ of DNA to 20 optical density units at $260 \mathrm{~m} \mu$. Potency of the enzyme was expressed in terms of deoxyribonuclease units $/ \mathrm{mg}$ protein $/ \mathrm{ml}$ reaction mixture. One optical density $/ 1 \mathrm{~cm}$ light path at $280 \mathrm{~m} \mu$ is assumed to have a protein concentration of $1 \mathrm{mg} / 1 \mathrm{ml}$.

Determination of phosphomono- and phosphodiesterase activitiesThese enzymes were estimated essentially according to the method of Bjork ${ }^{13)}$ except: that buffer solutions were replaced by ammonium acetate of $\mathrm{pH}$ 5.5. The molarity of $\mathrm{NaOH}$, added for termination of reaction and coloration of free paranitrophenol, was also increased from 0.05 to $0.2^{14)}$ in the present experiment.



Fig. 1. DEAE-cellulose column chromatography $(5 \times 30 \mathrm{~cm})$ of acetone fraction. 


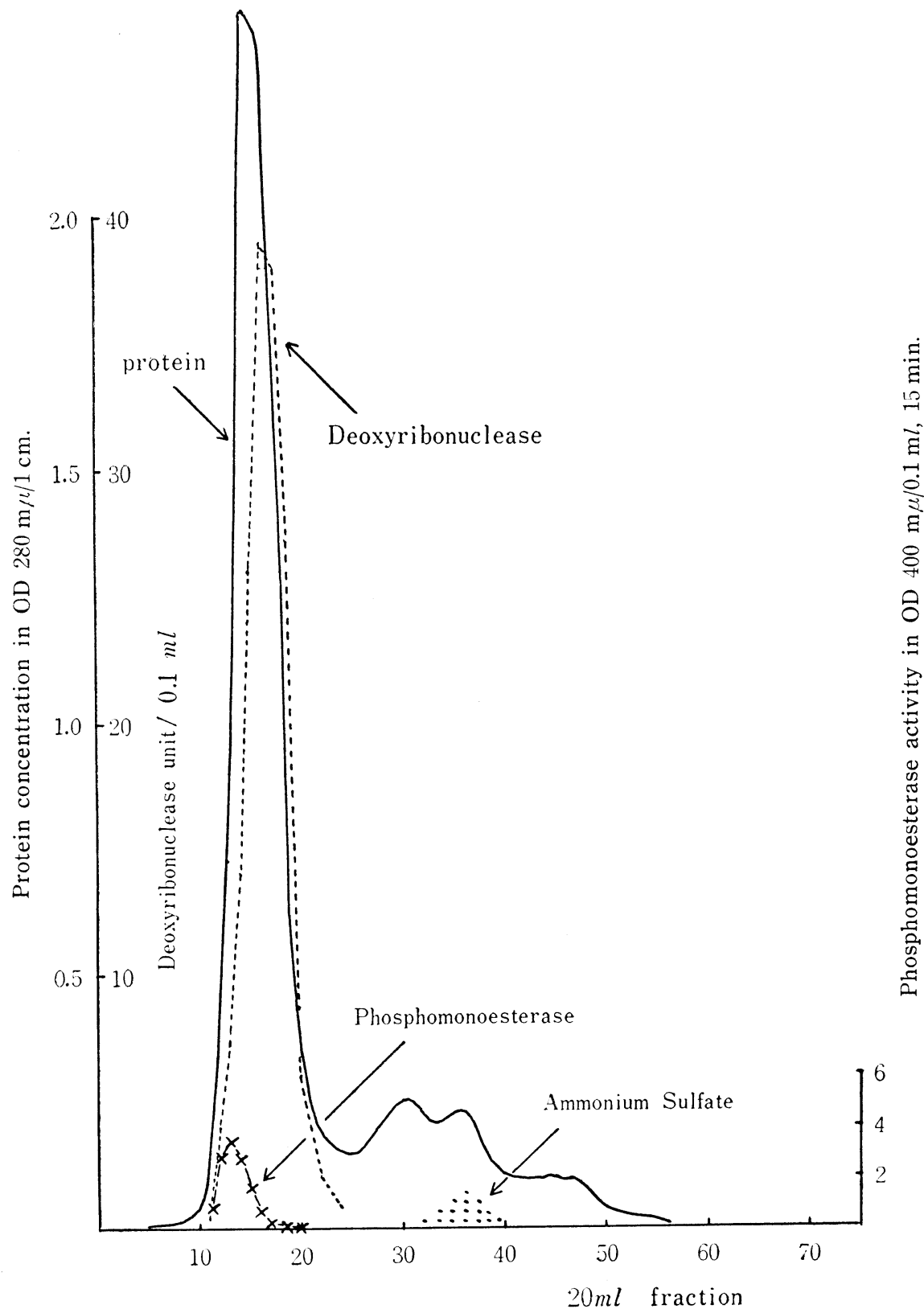

Fig. 2. Gel filtration through Sephadex G-75 $(5 \times 35 \mathrm{~cm}$, in $0.1 \mathrm{M}$ acetate, $\mathrm{pH} 6.5$ ). 
Purification of deoxyribonuclease, with special consideration of the elimination of phosphatases

All the steps were processed at $0-5^{\circ} \mathrm{C}$. Initial ammonium sulfate and acetone steps were found suited for concentration of deoxyribonuclease activity. Chromatographies on DEAE-and CM-cellulose columns as well as gel filtration through Sephadex G-75 at later steps proved effective for the separation of deoxyribonuclease and phosphomonesterase. The complete removal of the last trace of the contaminant, however, could not be attained so far. CM-cellulose column step was usually accompanied by a considerable loss. The results are shown in Fig. 1, 2 , and 3 , and are summarized in Table 1 .

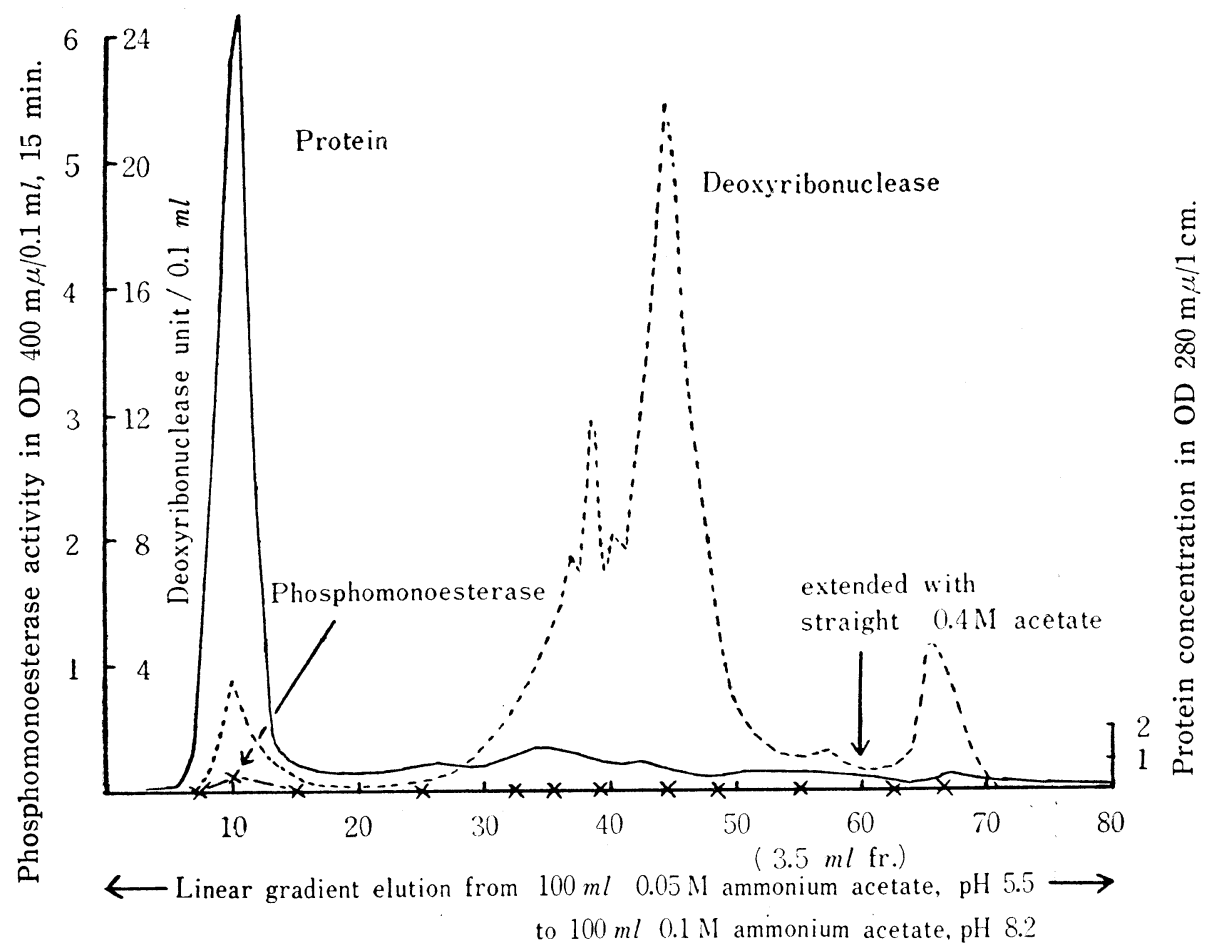

Fig. 3. CM-cellulose column chromatography $(0.8 \times 40 \mathrm{~cm})$ of Sephadex filtrate. 
Table 1. Summary of purification procedure.

\begin{tabular}{c|c|c|c|c|c|c}
\hline Step & Volume & OD 280 & $\begin{array}{c}\text { Total } \\
\text { protein }\end{array}$ & Potency & $\begin{array}{c}\text { Total } \\
\text { activity }\end{array}$ & Recovery \\
$\begin{array}{c}\text { Crude extract from } \\
\text { 1 kg of rice bran }\end{array}$ & 461.0 & 284 & 1310000 & 0.069 & 90390 & $100 \%$ \\
$\begin{array}{c}\text { Ammonium sulfate } \\
\begin{array}{c}\text { Ppt., 0.35-0.60 } \\
\text { saturation }\end{array}\end{array}$ & 1215 & 49.8 & 60500 & 1.46 & 88400 & 98 \\
$\begin{array}{c}\text { Acetone Ppt., 33-55\%, } \\
\text { at pH 7.5 }\end{array}$ & 94 & 60.1 & 5650 & 9.3 & 52600 & 58 \\
$\begin{array}{c}\text { DEAE-cellulose fr., } \\
\text { Tube No. 65-85 }\end{array}$ & 382 & 1.52 & 581 & 52.5 & 30500 & 33 \\
$\begin{array}{c}\text { Sephadex G-75 fr., } \\
\text { Tube No. 15-20 }\end{array}$ & 107 & 1.00 & 107 & 260 & 27100 & 31 \\
$\begin{array}{c}\text { CM-cellulose fr., } \\
\text { Tube No. 42 }\end{array} 43$ & 3.6 & 0.246 & 0.89 & 566 & & \\
44 & " & 0.218 & 0.79 & 737 & & \\
45 & 0.202 & 0.73 & 1120 & & \\
46 & " & 0.182 & 0.66 & 712 & & \\
\hline
\end{tabular}

Table 2. Selective inhibition of phosphomonoesterase.

\begin{tabular}{|c|c|c|}
\hline Relative activity of & Deoxyribonuclease & Phosphomonoesterase \\
\hline \multicolumn{3}{|l|}{ In the presence of: } \\
\hline None (Control) & 100 & 100 \\
\hline 0.01 M EDTA & 69 & 114 \\
\hline $0.001 \mathrm{M} \quad 1$ & 96 & 116 \\
\hline $0.01 \mathrm{M} \mathrm{MgCl}_{2}$ & 78 & 114 \\
\hline $0.001 \mathrm{M} "$ & 96 & 111 \\
\hline $0.01 \mathrm{M} \mathrm{CaCl}_{2}$ & 83 & 108 \\
\hline $0.001 \mathrm{M} \quad "$ & 98 & 116 \\
\hline $0.01 \mathrm{M} \mathrm{NaF}^{*}$ & 100 & 5 \\
\hline $0.001 \mathrm{M} " *$ & 101 & 25 \\
\hline $0.01 \mathrm{M} \mathrm{Na}$ arsenate* & 100 & 26 \\
\hline $0.001 \mathrm{M} \quad$ " * & 100 & 41 \\
\hline $0.01 \mathrm{M}$ phosphate & 59 & 11 \\
\hline $0.001 \mathrm{M} \quad$ " & 82 & 24 \\
\hline
\end{tabular}

* Overnight incubation 


\section{Properties of deoxyribonuclease and contaminating phosphomonoesterase}

Optimal acidity was found to be around $\mathrm{pH} 5.5$ both for deoxyribonuclease and for phosphomonoesterase. Both were shown to require no special ions for full activity. These observations at first seemed discouraging in thinking of using the nuclease as a tool for the structural studies of DNA, because of the reason mentioned in the introductory remarks. Fortunately, however, the sensitivities of the two enzymes against fluoride ion were found quite dissimilar. As is shown in Table 2, the deoxyribonuclease was not affected at all whereas phosphomonoesterase was inhibited by $95 \%$ at $0.01 \mathrm{M}$ fluoride concentration even in an overnight incubation. This difference was made use of in the digestion experiment designed for specificity study.

\section{Specificity of rice bran deoxyribonuclease}

Three hundreds and twenty four $\mathrm{mg}$ of thymus DNA in $12 \mathrm{ml}$ of water was incubated with $9.4 \mathrm{ml}$ of CM-cellulose eluates (Tube No. 43,44 , and 45) in three portions, at pH5.5 and in the presence of $0.01 \mathrm{M}$ fluoride, for 48 hours at $37^{\circ} \mathrm{C}$. The mixture was neutralized to $\mathrm{pH} 7.5$ by concentrated ammonia and deproteinized by Sevag's ${ }^{15\rangle}$ method. The material, after freed from the solvent odour by suction in a desiccator, was filled up to $25 \mathrm{ml}$ in a measuring flask. An $8 \mathrm{ml}$ fraction was pipetted out, diluted with $500 \mathrm{ml}$ of water, and made alkaline to $\mathrm{pH} 10.5$ by concentrated ammonia. It was in turn loaded on a column $(1 \times 9 \mathrm{~cm})$ of Dowex 1 acetate, and fractionally eluted according to the method of Sinsheimer. ${ }^{16)}$ The pattern is profiled in Fig. 4. A break-thru peak, emerging with a buffer front and so oc-

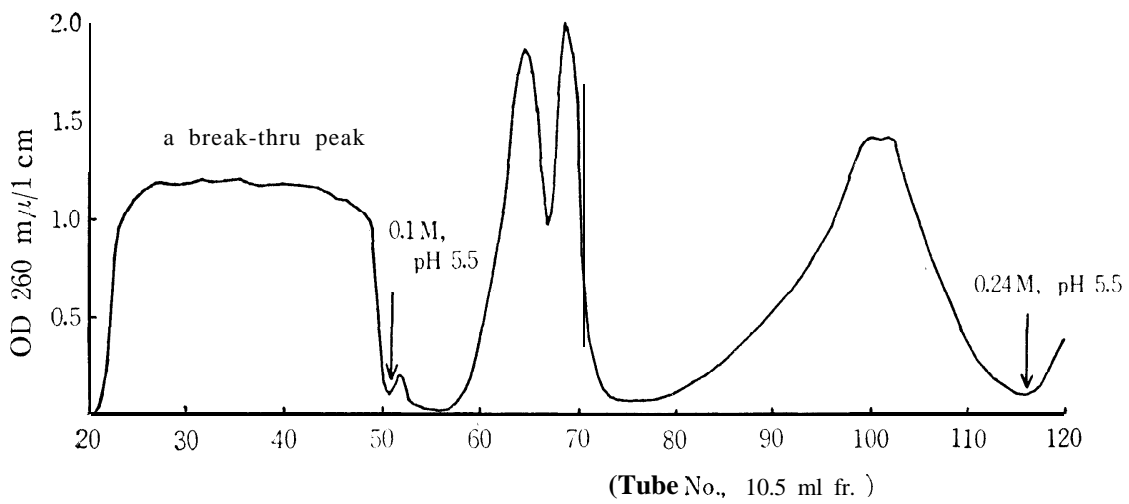

Fig. 4. Initial fractionation of deoxyribonuclease digest on Dowex-I acetate $(1 \times 9 \mathrm{~cm})$. 
cupying the place expected for free bases and nucleosides, was first examined, for it was unbelievable in view of the fact that only $0.3 \%$ of the total phosphorus was liberated as inorganic. It turned out as follows. It remained on a starting line when subjected to paperchromatography with $86 \%$ n-butanol as a solvent, indicating it is phosphorylated. Bases and nucleosides would move.") It was observed undiffusible through Visking cellophane tubing bag and insoluble in $0.5 \mathrm{~N}$ perchloric acid. It was also found that the material could not be retained on a charcoal column. Bases, nucleosides, and nucleotides of low molecular weights would be strongly held. Sedimentation constant measured by Spinco Ultracentrifuge Model E was 6.7. It looked homogeneous in the field. It yielded adenine, guanine, cytosine, and thymine on hydrolysis by $60 \%$ perchloric acid at $100^{\circ} \mathrm{C}$. It was thus settled that the material is of a polynucleotide nature too large in size to penetrate into a net-work of Dowex resin with $2 \%$ cross linkage.

The mononucleotide fraction, eluted with $0.1 \mathrm{M}$ ammonium acetate at $\mathrm{pH} 5.5$, was rechromatographed on a column $(1 \times 20 \mathrm{~cm})$ of Dowex 1 formate using a gradient elution system of Canellakis and Mantsavinos. ${ }^{18)}$ Three separate peaks were obtained. They showed the spectra characteristic of deoxymononucleotides of cytosine, thymine, and adenine in order of elution. Each of them was desalted by charcoal method and incubated separately with crude venom of "Habu "(Trimeresurus flavobilides) and with the purified venom phosphodiesterase in the presence of $0.01 \mathrm{M} \mathrm{Mg}$ at $\mathrm{pH} 9$ for 4 hours at $37^{\circ} \mathrm{C}$. Specificities and application of these venom enzymes have been established. ${ }^{19}$ ) Each fraction yielded quantitatively the corresponding nucleoside by the action of crude venom, showing that they are phosphorylated at $5^{\prime}$ position. All of them were found resistant against the phosphodiesterase action, indicating that they are not dinucleoside monophosphates, which should, if present, occupy the same place as mononucleotides under the elution condition used. Identification of three $5^{\prime}$-deoxymononucleotides was thus attained, excluding the possibility of dinucleoside monophophates. Deoxyguanylic acid could not be detected.

\section{Discussion}

This rice bran deoxyribonuclease is peculiar in the fact that it is a 5'-phosphate former in spite of its acting at acidic $\mathrm{pH}$ and requiring no $\mathrm{Mg}$ ion. Anyway it will be designated as deoxyribonuclease I. The next thing worthy to mention is that the enzyme leaves a fairly large amount of higher oligonucleotides besides mononucleotides. This means an endonucleolytic action with a limited specificity. It is clear that either 5'-phosphodiester linkage or 3'-phosphate linkage of deoxy- 
guanosine residue is resistant from the result of mononucleotides analysis. At present it is impossible to tell which the case is. It will be clarified by examination of the terminal residues of di- and oligonucleotides in the digests.

\section{Summary}

A method of purification of a deoxyribonuclease I from rice bran was devised. Though it is not the final, the enzyme preparation is purified about 16,000 fold with respect to deoxyribonuclease activity, and the contamination of phosphatase is reduced to a trace. The $\mathrm{pH}$ optimum is 5.5. No metal ion is required. Deoxyguanylic acid alone was missing among 5'-mononucleotides identified in the digestion products. The enzyme action appears endonucleolytic.

Acknowledgment-1 am especially indebted to Prof. S. Akune for his unrestrained generosity throughout this experiment. It was supported in part by a grant from the Ministry of Education to him.

\section{References}

1) Schmidt, G. In the Nucleic Acids, Vol. 1, pp. 576 (1955), edited by Chargaff, E. and Davidson, J. N.

2) Laskowski, M. In the Enzymes, Vol. 5, pp. 123 (1960), edited by Boyer, P. D., Lardy, H. and Myrbäck, K.

3) Yoshida, S. J. Biochem. (Tokyo) 34, 23 (1941).

4) Contardi, A. and Ravazoni, C. Arch. Ital. Biol. 92, 64 (1935).

5) Kay, E. R. M., Simmons, N. S. and Dounce, A. L. J. Amer. Chem. Soc. 74, 1724 (1952).

6) Akune, S. and Mukai, J.-I. J. Seric. Sci. Japan 30, 73 (1961).

7) De Garilhe, M. P. and Laskowski, M. Biochim. et Biophys. Acta. 18, 370 (1955).

8) Laskowski, M. Arch. Biochem. 11, 41 (1946).

9) Brown, K. D., Jacobs, G. and Laskowski, M. J. Biol. Chem. 194, 445 (1952).

10) Mukai, J.-I. J. Agr. Chem. Soc. Japan. 33, 733 (1959).

11) Lehman, I. R., Roussos, G. G. and Pratt, E. A. J. Biol. Chem. 237, 819 (1962).

12) Nakao, Y. and Ogata, A. Agr. Biol. Chem. 27, 199 (1963).

13) Björk, W. J. Biol. Chem. 238, 2487 (1963).

14) Ohsaka, A., Mukai, J.-I. and Laskowski, M. J. Biol. Chem. 239, 3498 (1964).

15) Sevag, H. G., Lackman, D. B. and Smolens, J. J. Biol. Chem. 124, 425 (1938).

16) Sinsheimer, R. L. J. Biol. Chem. 208, 445 (1954).

17) Wyatt, G. R. In the Nucleic Acids, Vol. 1, pp. 252 (1955), edited by Chargaff, E. and Davidson, J. N.

18) Canallakis, E. S. and Mantsavinos, R. Biochim. et Biophys. Acta 27, 643 (1958).

19) Mukai, J.-I. J. Agr. Chem. Soc. Japan. 34, 501 (1960) ; ibid.: unpublished result\& 